\title{
Identification keys to the Anopheles mosquitoes of South America (Diptera: Culicidae). IV. Adult females
}

\author{
Maria Anice Mureb Sallum ${ }^{*}$, Ranulfo González Obando², Nancy Carrejo ${ }^{2}$ and Richard C. Wilkerson 3,4,5
}

\begin{abstract}
Background: Morphological identification of adult females of described species of the genus Anopheles Meigen, 1818 in South America is problematic, but necessary due to their differing roles in the transmission of human malaria. The increase in the number of species complexes uncovered by molecular taxonomy challenges accurate identification using morphology. In addition, the majority of newly discovered species have not been formally described and in some cases the identities of the nominotypical species of species complexes have not been resolved. Here, we provide an up-to-date key to identify Neotropical Anopheles species using female external morphology and employing traditionally used and new characters.

Methods: Morphological characters of the females of South American species of the genus Anopheles were examined and employed to construct a species/group identification key. Photographs of key characters were obtained using a digital Canon Eos T3i, attached to a microscope. The program Helicon Focus was used to build single in-focus images by stacking multiple images of the same structure.

Results: A morphological identification key to the adult females of species of the genus Anopheles described in South America is presented. Definitions and illustrations of the key characters are provided to facilitate use of key.

Conclusions: Identification of species of the genus Anopheles based on female morphology is challenging because some key characters can be variable and overlapping among species. In addition, the majority of key characters are linked to color and shape of scales, their distribution on the head, scutum, abdomen, maxillary palpi, labium and legs, and pattern of pale and dark scales on dorsal and ventral surfaces of the wing veins. Thus, it is understandable that a specimen needs to be in good condition to be accurately identified. Morphologically similar species, such as those of the Konderi, Oswaldoi, Nuneztovari, Benarrochi and Albitarsis Complexes, and the Triannulatus and Strodei Groups, among others, cannot be accurately identified using characters included in the key. Further investigation will be required to exploit morphological characteristics for identification of members of those complexes, with formal description of new species.
\end{abstract}

Keywords: Anopheles, Illustrated key, Morphology, Identification, South America

*Correspondence: masallum@usp.br

1 Departamento de Epidemiologia, Faculdade de Saúde Pública,

Universidade de São Paulo, Avenida Doutor Arnaldo 715, São Paulo, São Paulo CEP01246-904, Brazil

Full list of author information is available at the end of the article

\section{Background}

General introductory comments, distributions and species authors and publication dates are given in Part I [1] of this series of four articles. Keys to fourth-instar larvae and male genitalia are in Parts II [2] and III [3], respectively. Despite many recent studies have focused on the importance of DNA sequences for uncovering species

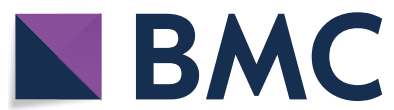

(c) The Author(s) 2020. This article is licensed under a Creative Commons Attribution 4.0 International License, which permits use, sharing, adaptation, distribution and reproduction in any medium or format, as long as you give appropriate credit to the original author(s) and the source, provide a link to the Creative Commons licence, and indicate if changes were made. The images or other third party material in this article are included in the article's Creative Commons licence, unless indicated otherwise in a credit line to the material. If material is not included in the article's Creative Commons licence and your intended use is not permitted by statutory regulation or exceeds the permitted use, you will need to obtain permission directly from the copyright holder. To view a copy of this licence, visit http://creativeco mmons.org/licenses/by/4.0/. The Creative Commons Public Domain Dedication waiver (http://creativecommons.org/publicdomain/ zero/1.0/) applies to the data made available in this article, unless otherwise stated in a credit line to the data. 
complexes [4-13], the identification of Anopheles species is primarily based on morphological characters of female, male, and fourth-instar larvae [1]. This paper provides an illustrated dichotomous morphological key for the identification of females of Anopheles species of South America.

\section{Methods}

The primary types (holotypes and paratypes) and other field-collected specimens deposited in the Coleção Entomológica de Referência, Faculdade de Saúde Pública, Universidade de São Paulo, São Paulo, Brazil (FSP-USP), Museo de Entomología, Universidad del Valle, Santiago de Cali, Colombia (MUSENUV) and the US National Mosquito Collection, Smithsonian Institution, Washington, DC, USA (USNMC) were selected and morphologically studied to discover additional characters to be used in the female key [1]. In addition, original descriptions, keys, summaries, and revisions from the published literature were examined. Photomicrographs of relevant characters for the female key were taken using a digital Canon Eos T3i (Canon, USA), attached to a stereomicroscope, using the program Helicon Focus software (https ://www.heliconsoft.com/heliconsoft-products/heliconfocus/), which was used to build single in-focus images by stacking multiple images of the same structure. Photomicrographs were further processed in Adobe Photoshop (https://www.photoshop.com/en) to embed names and labels. Table 1 in Sallum et al. [1] shows the traditional classification of the genus Anopheles. The female key was modified from Forattini [14], Wilkerson \& Strickman [15], and Harrison et al. [16] with further characters proposed herein.

\section{Results and discussion}

Identification of species of the genus Anopheles based on female morphology can, for various reasons, be inaccurate. Morphological similarities and overlapping characters are common in species of the genus Anopheles and will increase with further taxonomic studies using molecular tools to address identification, phylogeny and establish species complexes. In addition, increased sampling in remote and poorly sampled regions of South America will propitiate discovery of new species and improvement in the taxonomic knowledge and nomenclature of the group as well. The newly proposed identification key compiled morphological information for identification of females, however, ideally characters of the male genitalia, fourth-instar larvae, and scanning electron microscope of the eggs should be examined to increase accuracy. Employment of this key to identify both unknown species and those already defined by molecular approach should be considered with caution. Likely, a specimen that may belong to a species that was not formally named will be identified to a morphologically similar species. Thus, when facing morphological variations, further investigations will be necessary to verify if those observed differences can indicate an unknown species. It is highly recommended to examine all life stages to reach an accurate species identification using morphology.

\section{Morphological features}

The terminology of Harbach \& Knight $[17,18]$ is followed in the key below. Valid species of the genus Anopheles of the subgenera Anopheles, Kerteszia, Lophopodomyia, and Stethomyia found in South America are provided in Table 1 in Sallum et al. [1]. In addition to the morphological traits that identify members of the Culicidae Meigen, 1818, most females of the subfamily Anophelinae Grassi, 1900 differ from those of the subfamily Culicinae Meigen, 1818 by having the maxillary palpi as long as the proboscis. In the Anophelinae, the majority of the species of the genera Anopheles Meigen, 1818 and Bironella Theobald, 1905 have the posterior margin of the scutellum rounded, not developed with median and lateral lobes. Consequently, the scutellar setae are uniformly distributed along the posterior border (Fig. 1). However, it is noteworthy that some species of the subgenera Anopheles and Cellia Theobald, 1902 exhibit a shallow subdivision into three lobes, but the distinction between the median and lateral lobes is not as evident as in species of the genus Chagasia Cruz, 1906 (Fig. 2).

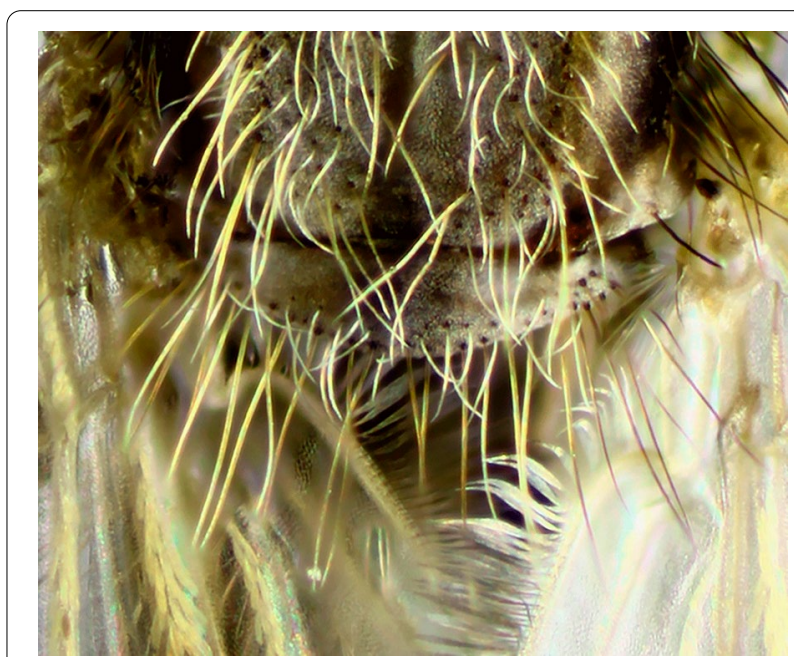

Fig. 1 Uni-lobed scutellum of an adult of An. (Ano.) pseudopunctipennis Theobald, 1901 


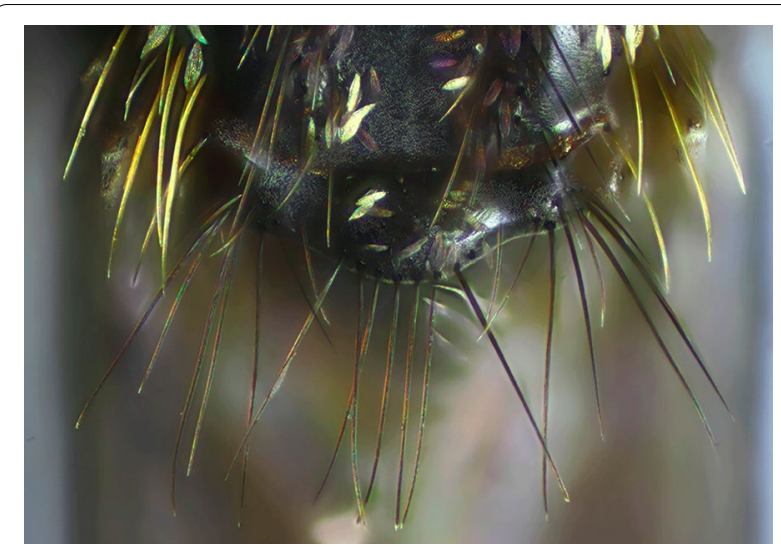

Fig. 2 Tri-lobed scutellum of an adult of the genus Chagasia Cruz, 1906

\section{Head}

Anopheles, like all other mosquitoes, have the antenna made up of 13 elongate flagellomeres. Each flagellomere possesses short setae dispersed around it and a number of longer, stronger setae arising apically
(Fig. 3). In the males, the antenna possesses a higher concentration of longer and stronger setae disposed apically that form the flagellar whorl. The maxillary palpus of the females and males is made up of five palpomeres (Fig. 3). Palpomere $1\left(\mathrm{MPlp}_{1}\right)$ is the shortest, arising laterally to the clypeus. Palpomere $5\left(\mathrm{MPlp}_{5}\right)$ is longer than palpomere 1 but shorter than palpomeres 2,3 and $4\left(\mathrm{MPlp}_{2-4}\right)$, which are elongate. Scales covering the maxillary palpus vary in color from silvery white to cream to yellowish to dark brown and black. The pattern of distribution of pale and dark scales on the maxillary palpus can help identify some species of the genus Anopheles.

\section{Thorax}

The thorax of the majority of the species of the genus Anopheles is elongate and as in all mosquitoes is represented mostly by the mesonotum (Fig. 4). The color of the scutal integument varies from blackish to brownish to grayish and exhibits patterns of color and scale distributions that can be employed for identification of species, species groups and subgenera. Scales can

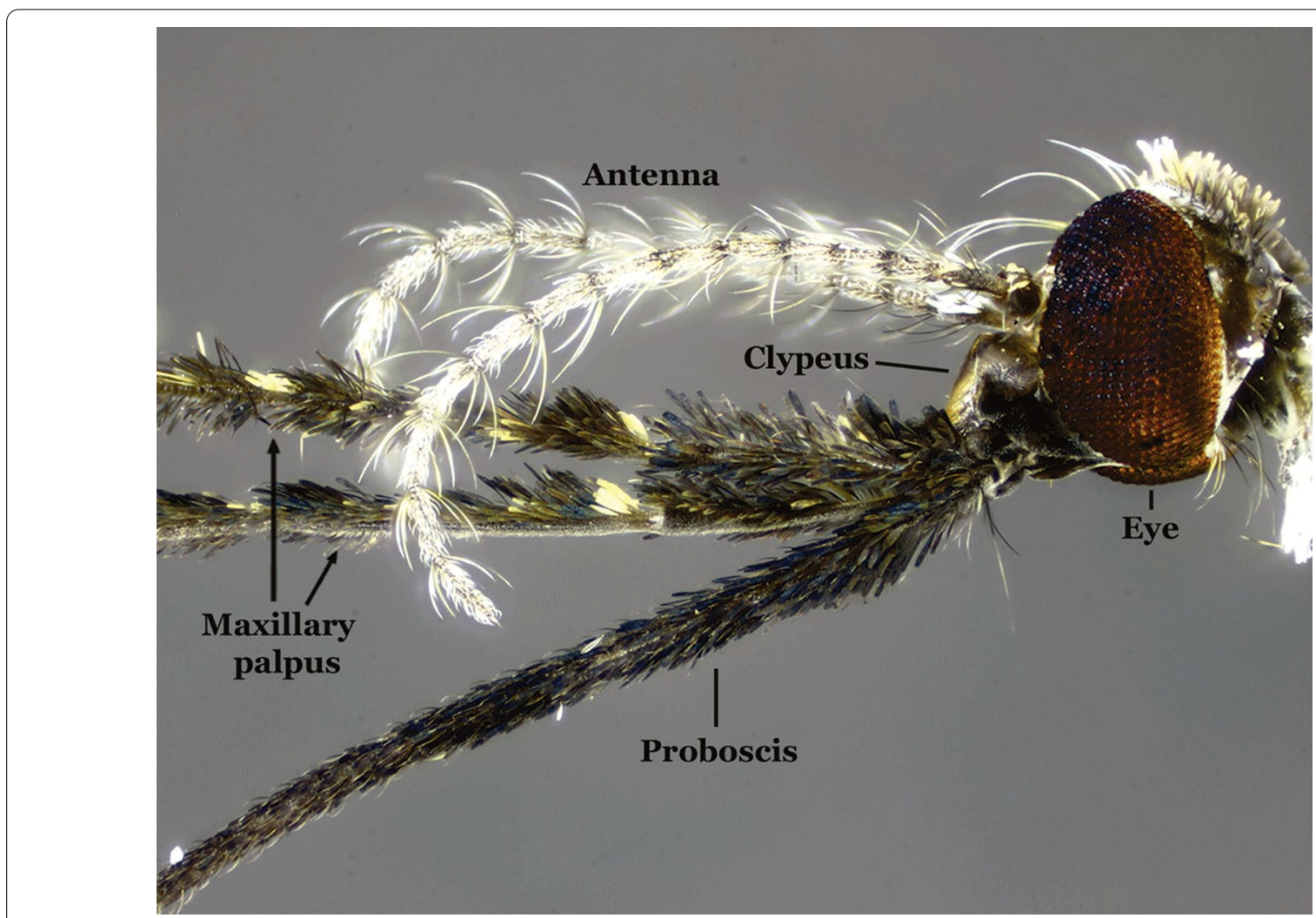

Fig. 3 Head of a female of An. (Ano.) calderoni Wilkerson, 1991 

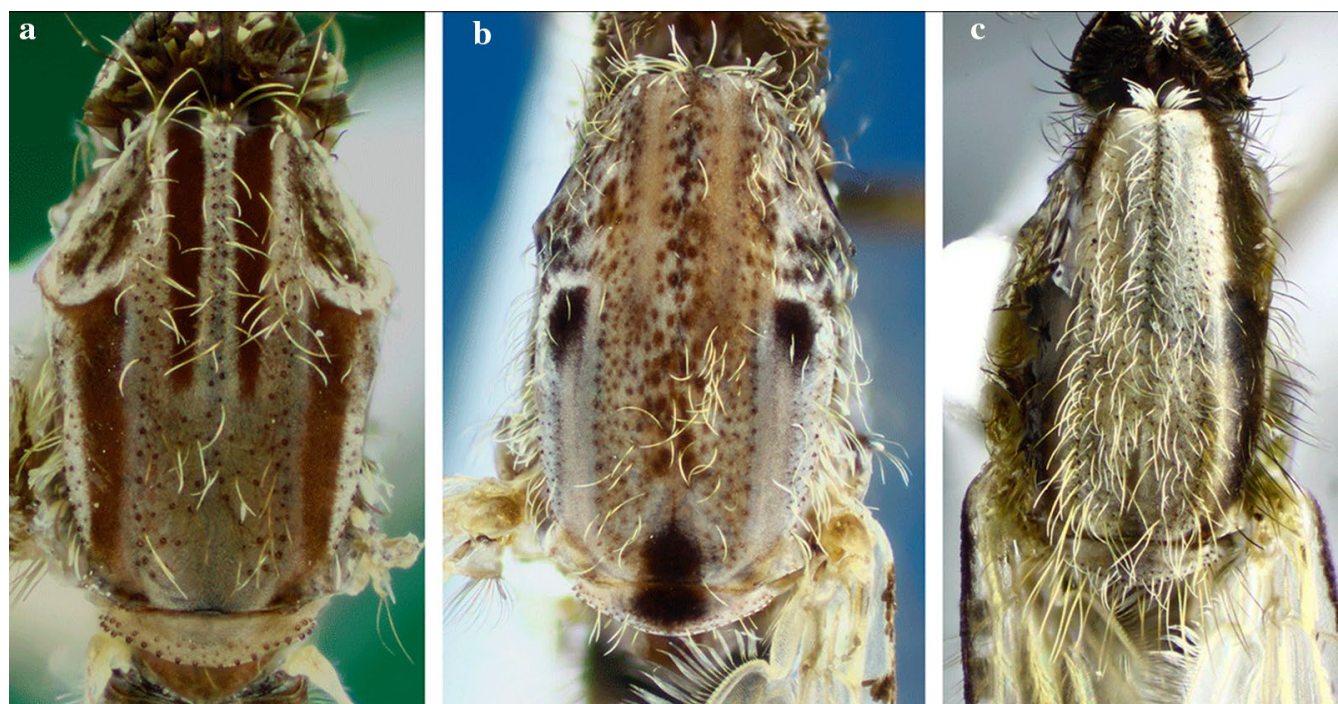

Fig. 4 Thoraces of Anopheles spp., dorsal aspects. a An. (Ker.) pholidotus Zavortink, 1973. b An. (Ano.) calderoni. c An. (Ano.) pseudopunctipennis

be absent or present. When present, scales are usually sparse and dispersed on some areas of the thoracic pleura (Fig. 5). The patterns of distribution of the scales on the mesokatepisternum and mesepimeron are frequently used to identify species of the subgenus Kerteszia Theobald, 1905 (Fig. 6).

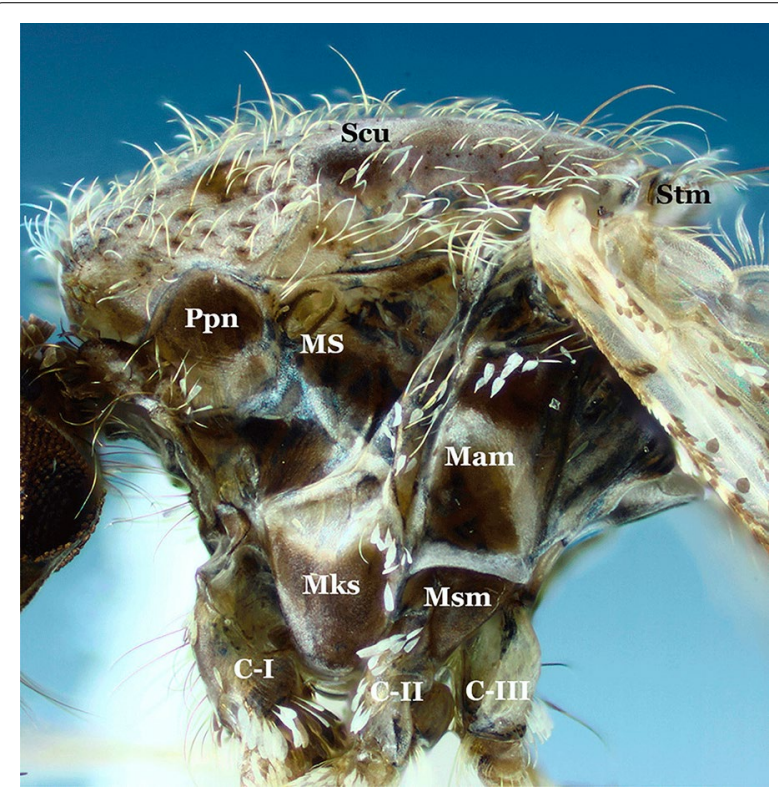

Fig. 5 Thorax of An. (Ano.) calderoni, lateral aspect. Abbreviations: C-I, forecoxa; C-II, midcoxa; C-III, hindcoxa; Mam, mesepimeron; Mks, mesokatepisternum; MS, mesothoracic spiracle; Msm, mesomeron; Ppn, postpronotum; Scu, scutum; Stm, scutellum

\section{Legs}

The legs of anophelines are predominantly dark but can have pale and dark scales in defined patterns or distributed without a characteristic pattern in the form of speckling. Some species have a defined pattern of scales, but there is also intraspecific and intra-individual variability. In other species, the legs are mostly dark-scaled, with pale scales forming rings and bands of variable size and distribution. On the hindlegs, the majority of species of the Arribalzagia Series of the subgenus Anopheles, as well as Nyssorhynchus Blanchard, 1902 and Kerteszia, have well-defined patterns of pale and dark scales that are often used for species identification. In species of the subgenus Nyssorhynchus, hindtarsomeres 2-5 are dark-scaled but show distinct patterns of pale scales that are employed for species identification (Fig. 7).

\section{Wings}

Independent of the shading or dark patterns that are sometimes seen on the wing membrane, the coloration of the scales that cover most of the wing veins is what defines the color of the wings. The scales vary from dark to pale, making the wings appear completely dark or with pale and dark areas that form patterns that are species-specific or group specific (Figs. 8, 9, 10, 11). This is usually evident on the longitudinal veins. The nomenclature adopted in the identification key is that proposed by Wilkerson \& Peyton [19]. The wing spots are named with reference to the pale and dark spots observed in $A n$. (Cellia) kochi Dönitz, 1901 and An. (Anopheles) of the 

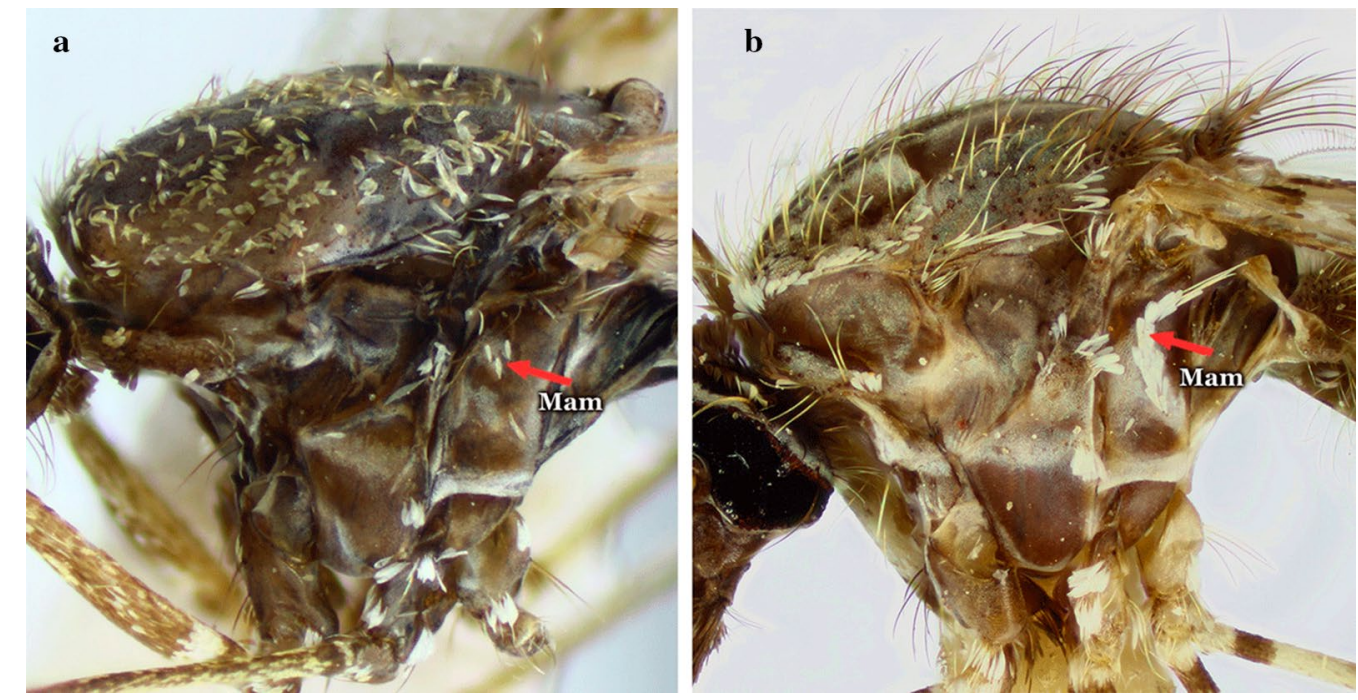

Fig. 6 Thoraces of Anopheles, lateral aspects. a An. (Nys.) darlingi Root, 1926. b An. pholidotus

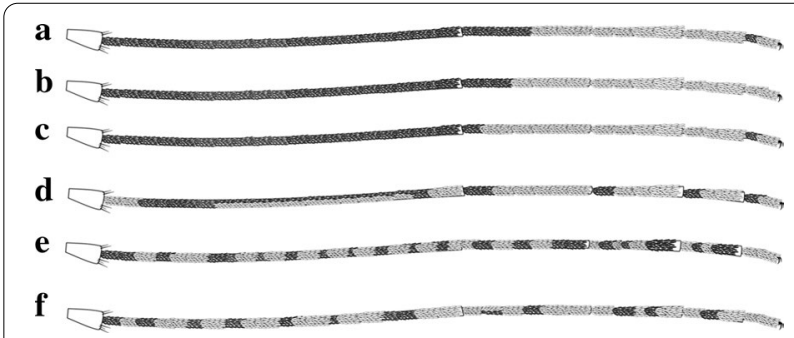

Fig. 7 Hindtarsomeres of Anopheles spp. females. a An. (Nys.) albimanus Wiedemann, 1820. b An. (Nys.) darlingi. c An. (Nys.) nuneztovari Gabaldon, 1940. d An. (Ker.) neivai Howard, Dyar \& Knab, 1913. e An. (Ano.) malefactor Dyar \& Knab, 1907. f An. (Ano.) costai da Fonseca \& da Silva Ramos, 1940

Arribalzagia Series (see Fig. 8a, b for names and abbreviations of wing spots).

\section{Abdomen}

Females of the genus Anopheles possess a variable pattern of scales, ranging from a dense covering (Fig. 12), i.e. Anopheles pharoensis Theobald, 1901 (an African species), to scales grouped in patches that are more evident on the dorsal portions of the segments, to almost entirely bare. The absence of scales on the abdominal segments is variable and is observed in species of diverse subgenera of the genus Anopheles. However, the abdomen is always covered with setae of variable development. The majority of the species of the subgenus Nyssorhynchus and some species of the subgenus Anopheles possess patches of scales grouped laterally at the posterior end of segments II-VII or III-VII or IV-VII. These patches of scales are called posterolateral scale-tufts (Fig. 11). In other species, scales are either absent or present only on segments VII and VIII and the cerci (Fig. 13). Abdominal sternum I is small and closely associated with the metathorax. Consequently, it is usually not easy to examine characteristics of sternum I when the specimen is dry-pinned, and the abdomen droops. Traits of sternum I are more easily seen if the individual is examined from a posterior view. In some species of the subgenus Nyssorhynchus, sternum I possesses sparse scales, or the scales are arranged in a longitudinal line (Fig. 14).

The morphological key provides diagnostic characters in couplets for identifications of specimens of species of the genus Anopheles of South America. The subgenus is marked in the couplet that is linked to the species of that taxonomic group. Characters employed in the key can be seen with a light stereomicroscope. Wing spots and scale color are critical and need to be examined with sufficient light that does not distort the color, ideally with a day light filter, and a microscope scale to calculate length ratios of some characters, such as fore- and hindtarsomeres, and dark and pale wing scale spots. 

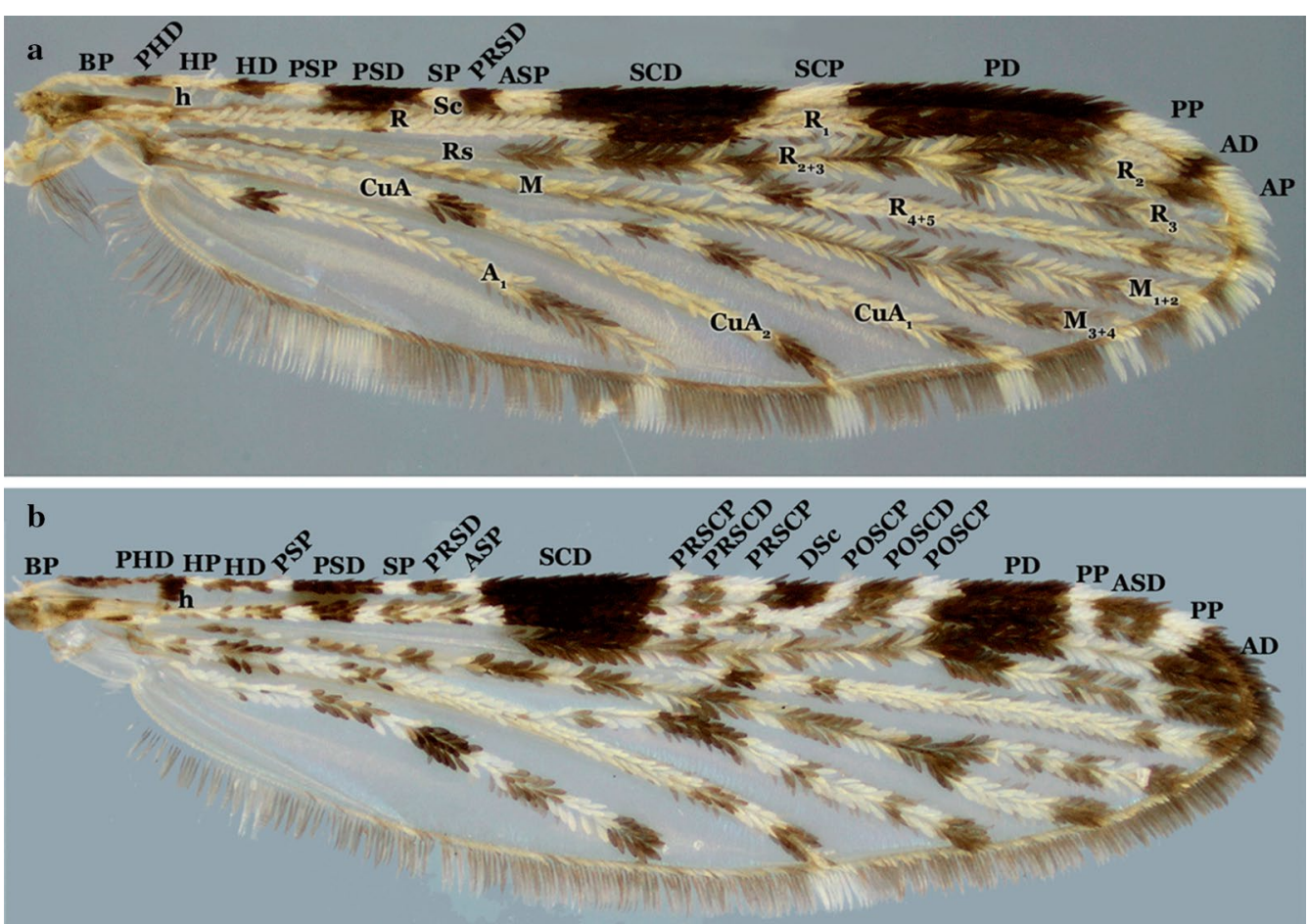

Fig. 8 Nomenclature of wing veins and of pale and dark spots on the dorsal surface of Anopheles spp. wings. a An. triannulatus. Abbreviations: BP, basal plate; PHD, prehumeral dark; HP, humeral pale; HD, humeral dark; PSP, presector pale; PSD, presector dark; SP, sector pale; PRSD, proximal sector dark; ASP, accessory sector pale; SCD, subcostal dark; DSD, distal sector dark (when the ASP is missing, the composite dark spot is termed the SD, sector dark); SCP, subcostal pale; PD, preapical dark; PP, preapical pale; AD, apical dark; AP, apical pale. b An. neomaculipalpus Curry, 1931. Dark and pale spot names and abbreviations follow [19]. Spots are listed from left to right; those shown in panel a are followed by additional spots shown in panel $\mathbf{b}$. Additional spots present in species of the Arribalzagia Series; subcostal vein ends in a AD, dark spot, SCD, subcostal dark in the middle of subcostal area. Spots basal to SCD are termed PRSCP, presubcostal pale and PRSCD, dark spots and those distal to it are the POSCP, postsubcostal pale and POSCD, dark spots. Also, in species of the series, the PP, preapical pale is interrupted by an ASD, accessory preapical dark
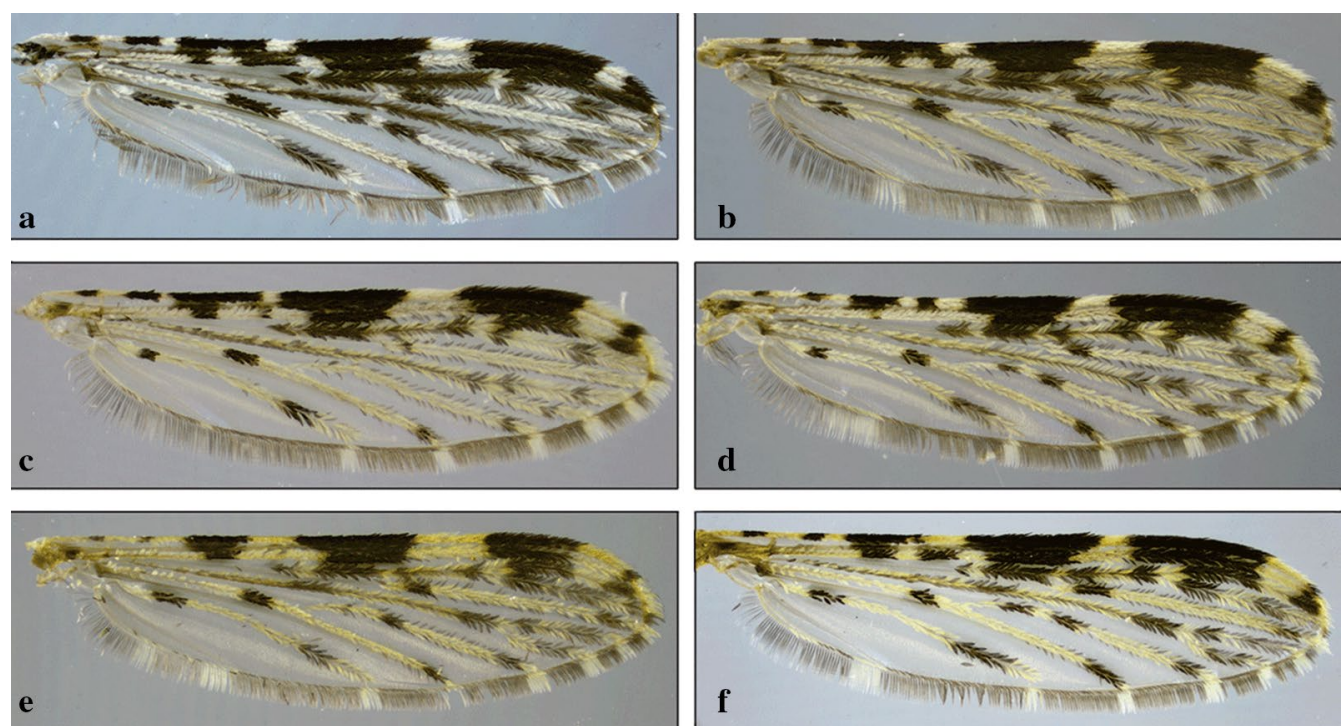

Fig. 9 Pale and dark wing spots in species of Anopheles (Nyssorhynchus). a An. braziliensis (Chagas, 1907). b An. albitarsis Lynch Arribálzaga, 1878. c An. strodei Root, 1926. d An. triannulatus (Neiva \& Pinto, 1922). e An. nuneztovari. f An. albimanus 

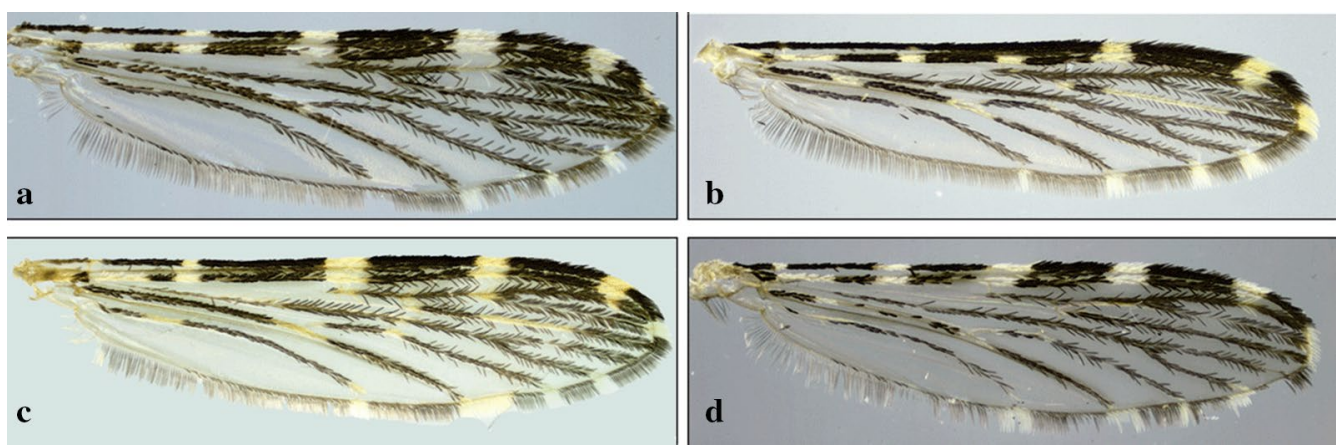

Fig. 10 Wings of species of Anopheles (Kerteszia). a An. pholidotus. b An. homunculus Komp, 1937. c An. gonzalezrinconesi Cova Garcia, Pulido F. \& Escalante de Ugueto, 1977. d An. neivai
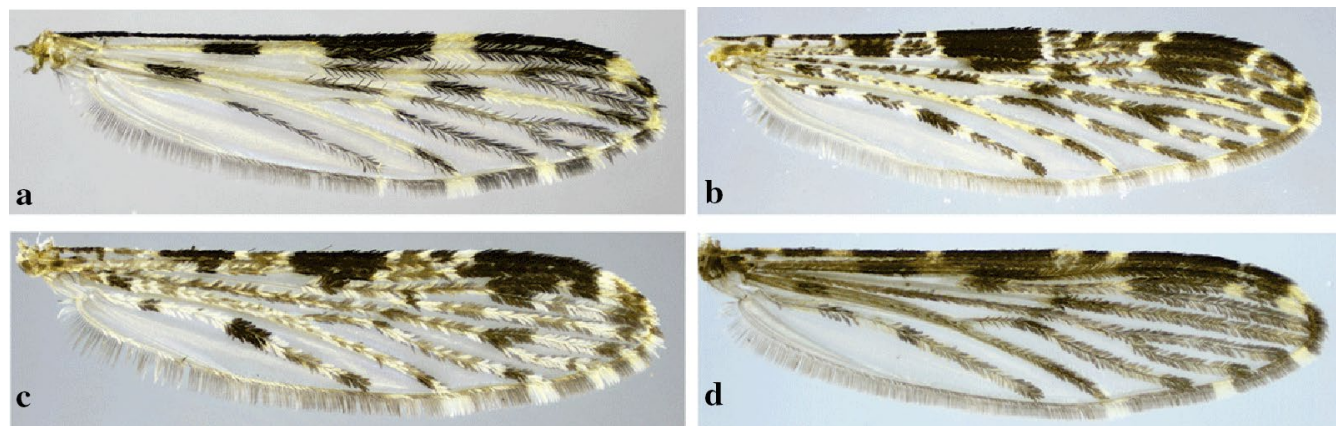

Fig. 11 Wings of species of Anopheles (Anopheles). a An. pseudopunctipennis. b An. calderoni. c An. peryassui Dyar \& Knab, 1908. d An. mattogrossensis Lutz \& Neiva, 1911
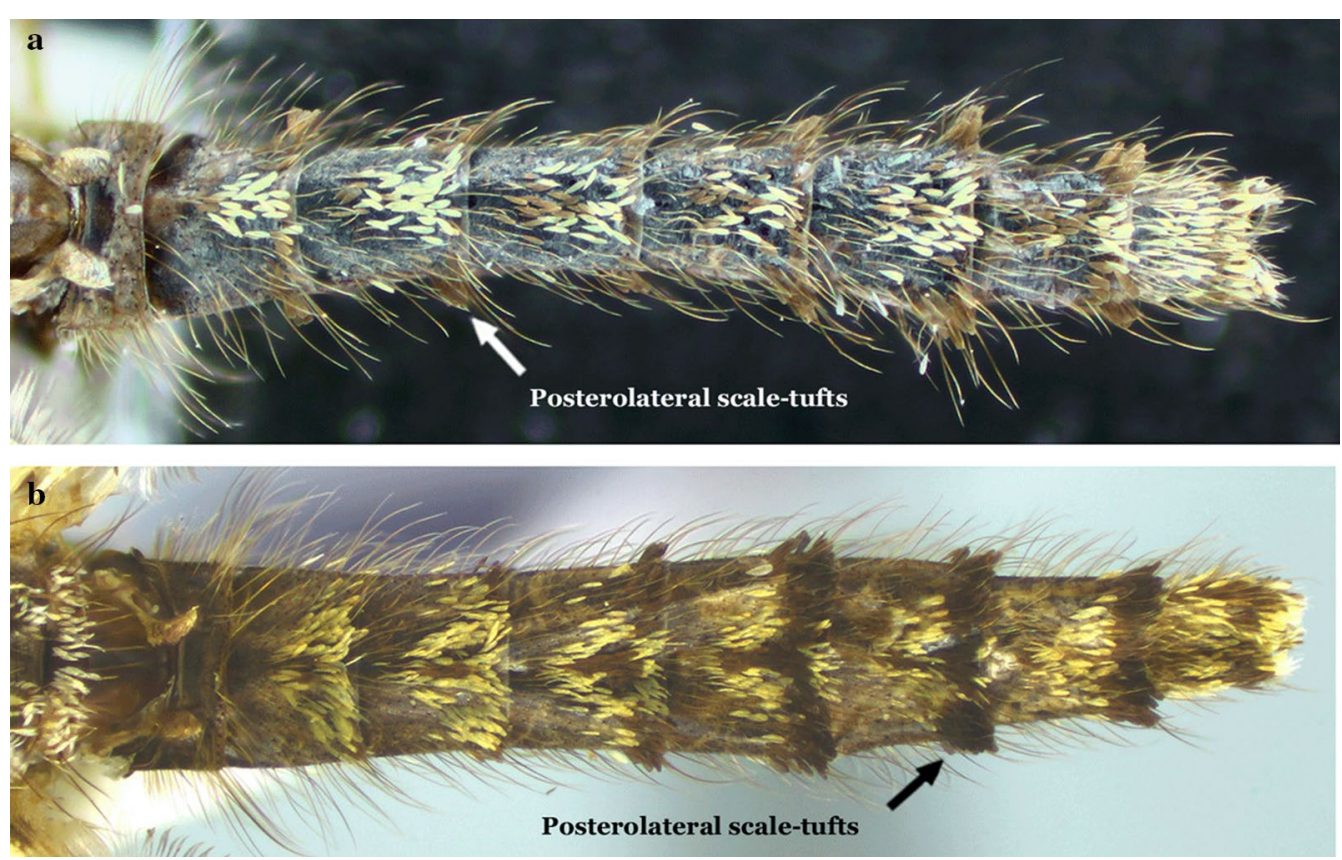

Fig. 12 Abdomens of Anopheles spp., dorsal view. a An. (Nys.) darlingi. b An. (Nys.) albimanus 

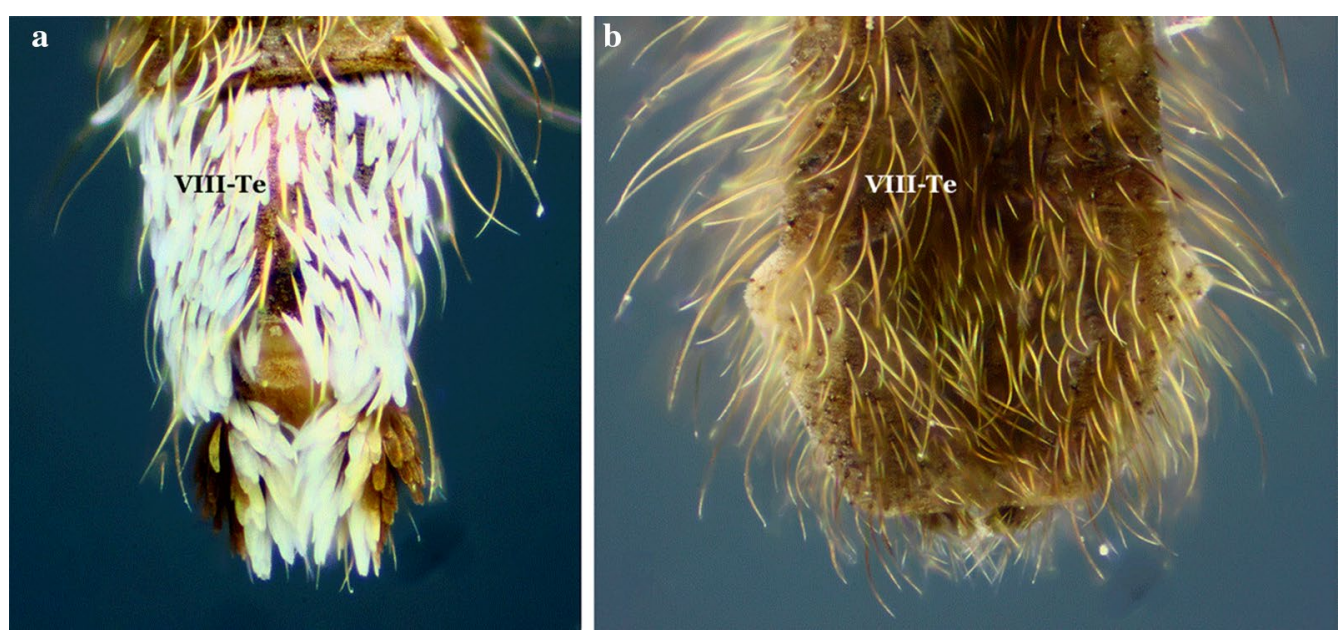

Fig. 13 End of abdomen; tergum VIII of Anopheles spp., dorsal view. a An. (Ano.) peryassui. b An. (Ano.) mattogrossensis

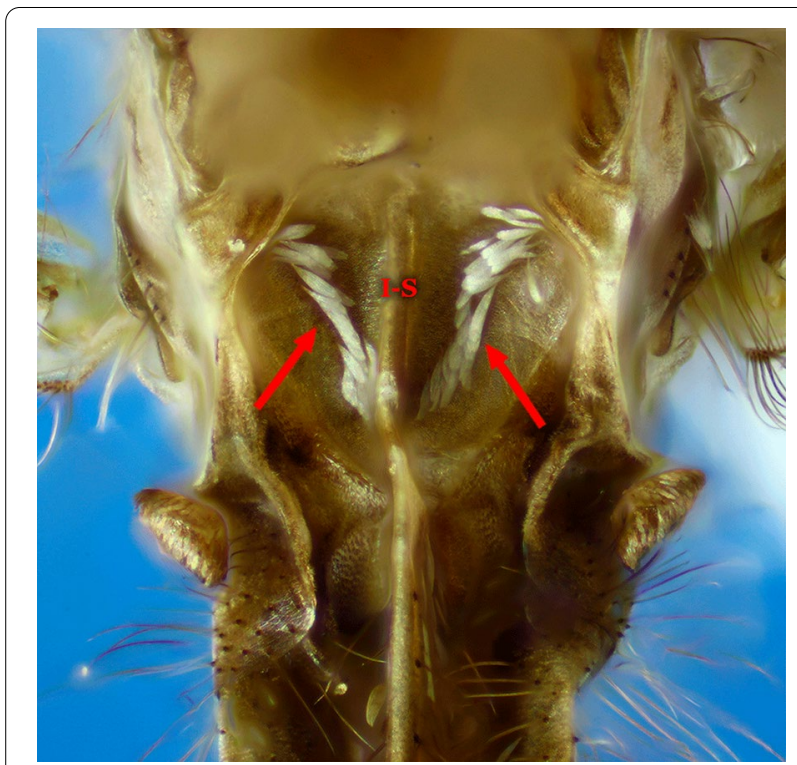

Fig. 14 Abdominal sternum I, An. (Nys.) albitarsis

\section{Key for the identification of species of the genus Anopheles of South America based on morphological characters of the adult females}

1a.Integument of scutum with a median longitudinal silvery stripe, dark laterally; head mostly without scales, except for some erect scales on vertex; wing veins and legs covered with dark scales (subgenus Stethomyia Theobald, 1902).

...2

1b Scutum otherwise; head with numerous erect scales on vertex and occiput; wing veins variably covered with pale and dark scales. 2a (1a) Setae and scales of the frontal tuft long, extending beyond antennal pedicels; lateral margin of the scutum with silvery stripe, as distinct and developed as the median stripe.

An. nimbus, An. thomasi \& An. acanthotorynus

$2 \mathrm{~b}$ Setae and scales of frontal tuft short, not extending beyond antennal pedicels; lateral margin of scutum, if with a silvery stripe, not as developed as median stripe. An. kompi \& An. canorii

$3 \mathrm{a}$ (1b) Integument of scutum with 4 distinct, longitudinal, silvery pruinose stripes intermixed with dark pruinose longitudinal stripes (subgenus Kerteszia)........... 4

3b Integument of scutum variable, not as above.............13 $4 \mathrm{a}$ (3a) Mesepimeron with a vertical C-shaped scalepatch (Fig. 6b) that begins at upper mesepimeral setae and continues ventrally.

5

4b Mesepimeron with 1 or 2 small white scale-patches

5a (4a) Proboscis, pedicel and palpomere $1\left(\mathrm{MPlp}_{1}\right)$ white-scaled; hindtarsomeres 1 and $2\left(\mathrm{Ta}-\mathrm{III}_{1,2}\right)$ without apical, pale bands (in dorsal view).......An. lepidotus

$5 \mathrm{~b}$ Proboscis, pedicel and palpomere $1\left(\mathrm{MPlp}_{1}\right)$ without white scales; hindtarsomeres 1 and $2\left(\mathrm{Ta}^{-\mathrm{III}_{1,2}}\right)$ with apical, pale bands (in dorsal view) (Figs. 4a, 6b, 10a) An. pholidotus

6a (4b)Mesepimeron with a small patch of scales inserted near the upper mesepimeral setae ..................7

6b Mesepimeron with 2 small patches of scales (upper and median)

7a (6a) Abdominal terga II-VII (II-VII-Te) covered with numerous dark decumbent scales; abdominal sterna with, sparse white scales (Fig. 10c). ...... An. boliviensis, An. gonzalezrinconesi \& An. rollai 
7b Abdominal terga and sterna without scales, occasionally with a few scales on segments VII and VIII and cerci.

$8 \mathrm{a}(7 \mathrm{~b})$ Hindtarsomere $5 \quad\left(\mathrm{Ta}-\mathrm{III}_{5}\right)$ entirely whitescaled; wing without pale apical fringe spot An. bambusicolus

$8 \mathrm{~b}$ Hindtarsomere 5 ( $\left.\mathrm{Ta}_{\mathrm{-}} \mathrm{III}_{5}\right)$ dark proximally, distal $0.35-$ 0.60 pale; wing with large pale apical fringe spot, rarely this spot divided into 2 small pale spots ...

9a (8b) Scutum with pale scales on acrostichal area, scales extending from anterior promontory nearly to prescutellar setae; hindtarsomeres $2-4$ ( $\left(\mathrm{Ta}-\mathrm{II}_{2-4}\right)$ each with narrow pale band on distal 0.15-0.5

An. auyantepuiensis

9b Scutum without pale scales on acrostichal area; hindtarsomeres 2-4 (Ta-III2-4) each with broad white band on distal 0.5-0.7 (Figs. 7d, 10d)

An. neivai (s.l.)

10a (6b) Hindtarsomeres 2-4 (Ta- $\left.-\mathrm{II}_{2-4}\right)$ each with narrow apical pale stripe 0.3 or less length of tarsomeres; hindtarsomere 5 ( Ta- $\mathrm{III}_{5}$ ) usually entirely dark-scaled, infrequently pale-scaled apically An. bellator

10b Hindtarsomeres 2-5 (Ta- $\left.-\mathrm{II}_{2-5}\right)$ each with a broad, apical pale band, extending from 0.4 to 0.7 . .11

11a (10b) Scutum with anterior 0.3-0.4 of acrostichal and dorsocentral areas and middle of scutellum with a few white scales; vein $M$ entirely or mostly white-scaled basal to level of bifurcation of vein $\mathrm{CuA}$ An. laneanus

11b Scutum without pale scales on acrostichal and dorsocentral areas and scutellum; vein $\mathrm{M}$ with dark scales basal to level of bifurcation of vein $\mathrm{CuA}$..........12

12a (11b) Palpomeres 3 and $4\left(\mathrm{MPlp}_{3,4}\right)$ covered predominantly by decumbent scales, sometimes those at base of palpomere $3\left(\mathrm{MPlp}_{3}\right)$ slightly erect .An. cruzii

12b Palpomere $3\left(\mathrm{MPlp}_{3}\right)$ covered with slightly erect scales, palpomere $4\left(\mathrm{MPlp}_{4}\right)$ with slightly erect to decumbent scales (Fig. 10b).

An. homunculus

13a (3b) Femora and tibiae unicolorous or variously marked, if speckled with pale and dark spots, dark spots are few and small; vein $C$ with a single small to large pale spot (subcostal pale, SCP) in vicinity of junction with subcostal vein $(\mathrm{Sc})$, or vein $\mathrm{C}$ entirely dark at junction with subcostal vein (Sc); sector pale spot (SP), if present, not interrupted by the accessory sector dark spot (ASD).

13b Femora and tibiae speckled with numerous large pale spots; vein $\mathrm{C}$ with a small to large dark spot (subcostal dark (SCD)) at junction with subcostal vein $(\mathrm{Sc})$, dark spot bordered on each side by one or more precoacal (PRSCP, PRSCD) and postsubcostal
(POSCP, POSCD) pale and dark spots; sector pale spot (SP) interrupted by an accessory sector dark (ASD) spot ....................................................................18 14a (13a) Hindfemur (Fe-III) with a distinct apical patch of erect dark scales....................An. squamifemur

14b Hindfemur (Fe-III) without an apical patch of erect dark scales................................................................15

15a (14b) Hindtarsomeres (Ta- III $\left._{1-5}\right)$ predominantly dark-scaled, without conspicuous pale stripes, at most with small basal spots or very narrow stripes of pale scales on some tarsomeres .................................16

15b Hindtarsomeres (Ta-III ${ }_{1-5}$ ) each with conspicuous pale apical stripe, or some posterior tarsomeres with conspicuous pale apical stripe and others completely white...........................................................................

16a (15a) Wings almost totally dark-scaled; pale spots, when present, limited in number and small

.17

16b Coloration of wing scales variable, spots pale or dark but with more and variable in length pale spots

W apices of veins $R_{2}, R_{3}$ and $R_{4+5}$; known distribution Central America .......................................An. eiseni eiseni

17b Wing fringe with distinct pale spots at apices of veins $R_{3}$ and $R_{4+5}$; known distribution South America ..............................................n. eiseni geometricus

18a (13b) Abdominal segments without erect or semi-erect posterolateral scale-tufts.............................19

18b Abdominal segments with erect or semi-erect posterolateral scale-tufts ................................................21

19a (18a) Tergum VIII (VIII-Te) densely covered with white or grayish scales, sometimes with dark scales basally and pale scales apically; scutum and scutellum with 3 distinct dark spots accentuated by silvery pruinosity, 2 spots situated laterally, posterior to wing, and 1 situated in prescutellar area, reaching anterior part of median lobe of scutellum (Figs. 11a, 13a) ............................................................ An. peryassui

19b Tergum VIII (VIII-Te) without white scales; integument of scutum and scutellum homogeneously dark without pattern or pruinose patches of dark spots . .20

20a (19b) Subcostal area (SCA) on vein C with 1 dark and 2 pale spots; subcostal area on veins $R_{1}$ and $\mathrm{R}_{2+3}$ predominantly pale-scaled; preapical dark spot (PD) fused with the accessory preapical dark (APD); preapical pale spot (PP) present at apex of vein $R_{1}$ An. vestitipennis

20b Subcostal area on vein $C$ with 1 dark and 2 pale spots; subcostal area (SCA) on veins $R_{1}$ and $R_{2+3}$ predominantly dark-scaled; preapical dark area (PD) separated from accessory preapical dark (APD), 
preapical pale area $(\mathrm{PP})$ with 2 pale spots, interrupted by accessory preapical dark (APD) (Figs. 11d, 13b)

.An. mattogrossensis

21a (18b) Hindtarsomeres 2-4 ( Ta- $\left.\mathrm{III}_{2-4}\right)$ mostly dark-scaled, with only apical pale rings and some basal pale scales at articulations. . .22

21b Hindtarsomeres 2-4 ( $\left.\mathrm{Ta}-\mathrm{III}_{2-4}\right)$ with more palescaled areas than above.

.24

22a (21a) Hindtarsomere $1\left(\mathrm{Ta}-\mathrm{III}_{1}\right)$ with various pale spots. An. minor

22b Hindtarsomere 1 (Ta- $\left.\mathrm{III}_{1}\right)$, dark with an apical pale ring

....23

23a (22b) Wing vein $\mathrm{R}_{4+5}$ with a mixture of pale and dark spots; subcostal dark spot (SD) large, extending anteriorly from union of subcosta (Sc) with costa $(\mathrm{C})$; pre- and postsubcostal dark spots well defined. An. shannoni

23b Wing vein $\mathrm{R}_{4+5}$ with 3 distinct dark spots; subcostal dark spot (SD) small, confined to union of subcostal vein $(\mathrm{Sc})$ with costa; pre- and postsubcostal (PRSCP, POSCP) dark spots not well defined ................An. guarao 24a (21b) Hindtarsomere $5\left(\mathrm{Ta}-\mathrm{III}_{5}\right)$ entirely pale

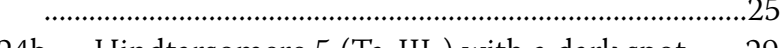

24b Hindtarsomere $5\left(\mathrm{Ta}^{\mathrm{b}} \mathrm{III}_{5}\right)$ with a dark spot.....29

25a (24a) Upper mesepimeral scales absent ............................................An. punctimacula (in part)

25b Upper mesepimeral scales present ........................26

26a (25b) Sternum I (I-S) with a small patch or line of scales (Fig. 7f) .An. mediopunctatus, An. costai \& An. forattinii

26b Sternum I (I-S) without scales....

27a (26b) Hindtarsomere $4\left(\mathrm{Ta}-\mathrm{III}_{4}\right)$ with 3 pale spots of variable size, sometimes entirely pale; postsubcostal dark spot (POSCD) on costa (C) small, poorly defined ..........................................An. fluminensis

27b Hindtarsomere $4\left(\mathrm{Ta}-\mathrm{III}_{4}\right)$ dark or with few pale scale-spots, never entirely pale; postsubcostal dark spot (POSCD) on costa (C) large, well-defined ........28

28a (27b) Wing with postsubcostal pale spot (POSCP) on costa $(\mathrm{C})$ contiguous with corresponding pale spot on $\mathrm{R}_{1}$ (Fig. 7e) . An. malefactor

$28 \mathrm{~b}$ Postsubcostal pale spot (POSCP) on costa (C) separated by dark scales from corresponding spot on $\mathrm{R}_{1}$ (Figs. 3, 4b, 5, 11b).... An. calderoni

29a (24b) Wing with narrow scales basally, scale length $\geq 3$ times width at widest point.................30

29b Wing with broad scales basally, scale length < 3 times width at widest point.

30a (29a) Wing with small preapical dark spot (PD), 0.06-0.12 length of wing; costa (C) with 2 primary dark spots (SD and PD), presector dark spot (PSD) reduced in size (Fig. 8)........An. neomaculipalpus 30b Wing with preapical dark spot (PD) larger, 0.110.23 length of wing; costa $(C)$ with 3 primary dark spots (SD, PD and PSD)

31a (30b) Hindtarsomere $3\left(\mathrm{Ta}-\mathrm{III}_{3}\right)$ with a basal dark ring; midtarsomere 5 ( $\left.\mathrm{Ta}-\mathrm{II}_{5}\right)$, completely dark; vein $R_{1}$ with the dark spot in subcostal area (SCA) interrupted by a pale spot in line with subcostal dark spot (SCD) on costa (C); accessory sector dark spot (ASD) on costa (C) does not clearly extending to vein $\mathrm{R}_{1}$ An. anchietai

31b Hindtarsomere $3\left(\mathrm{Ta}-\mathrm{III}_{3}\right)$, with a basal pale ring; midtarsomere $5\left(\mathrm{Ta}-\mathrm{II}_{5}\right)$ dark basally and pale apically; vein $\mathrm{R}_{1}$ with dark spot in subcostal area (SCA) without a pale interruption; accessory sector dark spot (ASD) on costa (C) clearly extends to vein $\mathrm{R}_{1}$ ..An. maculipes \& An.pseudomaculipes

32a (29b) Wing vein CuA mostly dark-scaled .....33

32b Wing vein CuA mostly pale-scaled........................36

33a (32a) Wing vein 1A with distal half darkscaled. An. bustamentei

$33 \mathrm{~b}$ Wing vein $1 \mathrm{~A}$ with pale and dark areas along entire length.

$34 \mathrm{a}(33 \mathrm{~b}) \quad$ Scales on middle portion of anterior cubital vein $(\mathrm{CuA})$ dark, scales decumbent and smaller than on other veins; anterior wing veins with 4 primary dark spots, apical dark spot (AD) as distinct as preapical dark (PSD), sector dark (SD) and preapical dark (PD) spots .........................An. apicimacula (in part)

34b Scales on middle portion of anterior cubital vein (CuA) not as above, predominantly pale or with a mixture of pale and dark scales, usually not decumbent, about same size as scales on other veins; anterior wing veins with 3 or 4 primary spots, apical dark spot (AD) either distinct or indistinct.............................35

35a (34b) Preapical dark spot (PD) on costa (C) shorter than sector dark spot (SD (DSD)

35b Preapical dark spot (PD) on costa (C) about same length as sector dark spot (SD (DSD)) ......An. calderoni

36a (32b) Wing vein $\mathrm{R}_{4+5}$ with 2 well-defined dark spots, one basal and the other apical; vein $1 \mathrm{~A}$ with 3 or 4 dark spots An. rachoui

36b Wing vein $\mathrm{R}_{4+5}$ with 4 well-defined dark spots, 2 basal and 2 apical; vein $1 \mathrm{~A}$ with 6 or more dark spots

37a (36b) Postsubcostal pale spot (POSCP) on costa $(C)$ not contiguous with corresponding spot on $\mathrm{R}_{1}$; costa $(\mathrm{C})$ straight at union of subcostal vein (Sc) An. evandroi

37b Postsubcostal pale spot (POSCP) on costa (C) contiguous with corresponding spot on $\mathrm{R}_{1}$; costa $(\mathrm{C})$ distinctly emarginated at union of subcostal vein $(\mathrm{Sc})$ 
38a (16b) Hindtibia (Ti-III) with a large pale area on apical 0.25 . . .39

38b Hindtibia (Ti-III) without a large apical pale area, at most with a small spot or pale ring ......

39a (38a) Vein 1A entirely dark-scaled.. An tibiamaculatus

39b Vein 1A with pale- and dark-scaled areas..... .40

40a (39b) Scutum covered with grayish or whitish pruinosity....... An. gilesi

40b Scutum covered with grayish pruinosity, forming a broad median longitudinal band, dark brown laterally..... An. pseudotibiamaculatus

41a (38b) Wing vein $1 \mathrm{~A}$ entirely dark-scaled, or at most with a small median pale spot............An. vargasi

41b Wing vein $1 \mathrm{~A}$ pale- or dark-scaled, if dark-scaled then always with more than 1 pale spot........................42

42a (41b) Hindfemur (Fe-III) and hindtibia (TiIII) uniformly dark, sometimes with small apical pale ring; costa $(C)$ with 2 pale spots, one at the point of union with subcosta (SCP), the other on preapical area (PP); vein $1 \mathrm{~A}$ with basal 0.5 dark-scaled, distal 0.5 pale-scaled, and with a small pale spot at apex (Figs. 4c, 11a).... An. pseudopunctipennis

42b Hindfemur (Fe-III) and hindtibia (Ti-III) speckled with white and yellow spots; costa $(C)$ with more than 2 pale spots; vein $1 \mathrm{~A}$ with a variable pattern of pale and dark spots .43

43a (42b) Wing vein $\mathrm{R}_{4+5}$ with 2 dark spots separated by an intermediate pale spot; vein $1 \mathrm{~A}$ with 3 dark spots An. oiketorakras

43b Wing vein $\mathrm{R}_{4+5}$ with 1 distal dark spot; vein $1 \mathrm{~A}$ with 2 dark spots An. gomezdelatorrei

44a (15b) Wing vein $1 \mathrm{~A}$ with about 5 pale spots interspersed with 6 dark spots, all small; hindfemur (Fe-III) and hindtibia (Ti-III) dark, speckled with pale spots of variable size; hindtarsomeres 4 and 5 (Ta$\mathrm{III}_{4,5}$ ), entirely white. An. annulipalpis

$44 \mathrm{~b}$ Wing vein 1A with fewer pale and dark spots; hindfemur (Fe-III) and hindtibia (Ti-III) dark with sparse pale scales, not speckled; hindtarsomeres 4 and $5\left(\mathrm{Ta}-\mathrm{III}_{4,5}\right)$ white or white with dark rings at

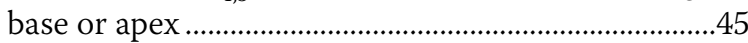

45a (44b) Abdominal terga (Te), at least segments II-VII (II-VII-Te), covered with scales ...........................46

45b Abdominal terga (Te) with or without sparse scales (Myzorhynchella Section). ....59

46a (45b) Hindtarsomere $5\left(\mathrm{Ta}-\mathrm{III}_{5}\right)$ with a basal dark spot. .. .47

46b Hindtarsomere $5\left(\mathrm{Ta}-\mathrm{III}_{5}\right)$ entirely white-scaled or with an apical dark ring... . .63

47a (46a) Abdominal segment II without posterolateral scale-tufts; palpomere $4\left(\mathrm{MPlp}_{4}\right)$ completely dark-scaled or with yellowish or golden-brown mediolateral scales, never white or cream-colored (Figs. 7a, 9f, 12b). An. albimanus

47b Abdominal segment II with posterolateral scaletufts; palpomere $4\left(\mathrm{MPlp}_{4}\right)$ differently marked, with at least some white or cream-colored mediolateral scales . .48

48a (47b) Anterior mesepimeron with a conspicuous white scale-patch; wing subcostal pale spot (SCP) reduced; prehumeral dark spot (PHD) extends to the humeral crossvein (h) (Figs. 8a, 9d)

An. halophylus, An. triannulatus \& An. triannulatus C

48b Anterior mesepimeron without a conspicuous white scale-patch, sometimes with 1 or 2 small pale scales; wing subcostal pale spot (SCP) variable, never reduced; prehumeral dark spot (PHD) variably devel-

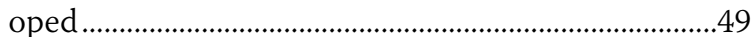

49a (48b) Hindtarsomere $3\left(\mathrm{Ta}-\mathrm{III}_{3}\right)$ variable, sometimes with a basal dark band $\leq 0.4$ length of tarsomere; prescutelar area covered with a distinct large dark spot.

An. rondoni

49b Hindtarsomere $3\left(\mathrm{Ta}-\mathrm{III}_{3}\right)$ completely pale; prescutelar area with a more-or-less distinct small spot, but never entirely covering prescutelar area..............50

50a (49b) Hindtarsomere $2\left(\mathrm{Ta}-\mathrm{III}_{2}\right)$ with a basal dark spot $<0.25$ length of tarsomere................ 51

$50 \mathrm{~b}$ Hindtarsomere $2\left(\mathrm{Ta}-\mathrm{III}_{2}\right)$ with a basal dark spot $>0.25$ length of tarsomere...............................................52

51a (50a) Foretarsomere $4\left(\mathrm{Ta}-\mathrm{I}_{4}\right)$ entirely pale or, rarely with more than basal 0.30 dark; midtarsomere 4. $\left(\mathrm{Ta}-\mathrm{II}_{4}\right)$ with an apical pale stripe corresponding to $0.15-0.25$ length of segment; foretarsomeres 3-5 (Ta- $\mathrm{I}_{3-5}$ ) mostly cream-colored, sometimes white, dark scales frequently present only on dorsobasal surface; foretarsomere $2\left(\mathrm{Ta}-\mathrm{I}_{2}\right)$ pale on apical $0.35-$ 0.55 ; foretarsomere $3\left(\mathrm{Ta}-\mathrm{I}_{3}\right)$ pale on apical $0.70-0.86$

An. ininii

51b Foretarsomere $4\left(\mathrm{Ta}-\mathrm{I}_{4}\right)$ entirely dark, at least on basal third; midtarsomere $4\left(\mathrm{Ta}-\mathrm{II}_{4}\right)$ entirely dark; foretarsomeres $3-5\left(\mathrm{Ta}-\mathrm{I}_{3-5}\right)$ with pale scales nearly forming a complete ring on all tarsomeres, dark scales occasionally absent on ventral surface; foretarsomere $2\left(\mathrm{Ta}-\mathrm{I}_{2}\right)$ pale on apical $0.20-0.45$; foretarsomere $3\left(\mathrm{Ta}-\mathrm{I}_{3}\right)$ pale on apical $0.50-0.85 \ldots . .$. An. oswaldoi \& An. konderi

52a (50b) Costa (C) with subcostal pale spot (SCP) $>0.5$ length of sector dark spot $(\mathrm{SD})$..............An. rangeli

$52 \mathrm{~b}$ Costa $(\mathrm{C})$ with subcostal pale spot $(\mathrm{SCP})<0.5$ length of the sector dark spot (SD) ..............................53

$53 \mathrm{a}(52 \mathrm{~b}) \quad$ Wing with vein $\mathrm{M}$ stem predominantly dark-scaled from apex to basal third, vein $M_{1}$ with predominantly dark scales....................An. bennarrochi

53b Wing with vein $M$ stem predominantly palescaled. .54 
54a (53b) Hindtarsomere $2\left(\mathrm{Ta}-\mathrm{III}_{2}\right)$ with dark spot extending beyond basal 0.5 .

...An. aquasalis \& An. galvaoi

54b Hindtarsomere $2\left(\mathrm{Ta}-\mathrm{III}_{2}\right)$ with dark spot never extending beyond basal 0.5 . ....55

55a (54b) Humeral pale spot (HP) on costa (C) < 2.0 length of prehumeral dark spot (PHD) ..................56

$55 \mathrm{~b}$ Humeral pale spot (HP) on costa $(\mathrm{C}) \geq 2.0$ length of prehumeral dark spot (PHD) ....57

56a (55a) Pale wing scales very pale to pale creamcolored; costa (C) with humeral pale spot (HP) 1.32.0 length of prehumeral dark spot (PHD).

An. dunhami \& An. trinkae

56b Pale wing scales, at least on anterior veins, yellowish to cream-colored; costa (C) with humeral pale spot (HP) 0.7-1.7 length of prehumeral dark spot (PHD) (Figs. 7c, 9e).

An. goeldii; An. nuneztovari (s.s.) \& An. nuneztovari A

57a (55b) Wing pale scales, at least on anterior veins, yellowish or grayish; foretarsomere $\left(\mathrm{Ta}-\mathrm{I}_{5}\right)$, pale-scaled apically, pale scales varying from yellowish to golden.

An. evansae

57b Wing with pale scales white; foretarsomere 5 (Ta$\mathrm{I}_{5}$ ) variously marked. . .58

58a (57b) Foretarsomere $5\left(\mathrm{Ta}-\mathrm{I}_{5}\right)$ white on apical 0.5 ..................................... An. dunhami \& An. trinkae

58b Foretarsomere 5 ( $\left(\mathrm{Ta}-\mathrm{I}_{5}\right)$ usually gold to grayish, sometimes dark-scaled on basal 0.5 (Fig. 9c)

An. strodei

59a (45b) Hindtarsomeres 3 and 4 ( Ta-III ${ }_{3,4}$ ) with a basal dark-scaled stripe.........................An. nigritarsis

59b Hind tarsomeres 3 and $4\left(\mathrm{Ta}-\mathrm{III}_{3,4}\right)$ entirely palescaled.

. .60

60a (59b) Wing vein $\mathrm{R}_{4+5}$, predominantly darkscaled........................................ An. lutzii \& An. guarani

60b Wing vein $\mathrm{R}_{4+5}$, predominantly pale-scaled.......61

61a (60b) Wing vein $R_{4+5}$, with 3 dark spots (1 prebasal, 1 median and 1 preapical), clearly separated by 2 pale spots.

.An. parvus

61b Wing vein $R_{4+5}$, with 2 distinct dark spots (1 prebasal and 1 preapical), region between the 2 dark spots, predominantly pale on dorsal surface of wing

62a (61b) Wing vein $\mathrm{CuA}_{2}$ pale-scaled on basal 0.5, dark-scaled on apical 0.5......................An. antunesi

62b Wing vein $\mathrm{CuA}_{2}$ with 3 distinct pale spots (1 basal, 1 median and 1 apical), interrupted by 2 dark spots interspersed with pale spots (1 prebasal and 1 preapical)........................................................ An. pristinus

63a (46b) Sternum I (I-S) without longitudinal lines of white scales, rarely with a few sparse scales 63b Sternum I (I-S) with 2 longitudinal lines of white scales . 69

64a (63a) Palpomere $5\left(\mathrm{MPlp}_{5}\right)$ with a dark spot on basal 0.4; scutal scales large; abdominal segments without posterolateral scale-tufts.

64b Palpomere $5\left(\mathrm{MPlp}_{5}\right)$ all pale; scutal scales small; abdominal segments with posterolateral scale-tufts at least on segments III-VII .66

65a (64a) Hindtarsomere $5\left(\mathrm{Ta}-\mathrm{III}_{5}\right)$ entirely palescaled.......................................................... An. pictipennis

65b Hindtarsomere $5\left(\mathrm{Ta}-\mathrm{III}_{5}\right)$ with an apical band of dark scales An. atacamensis

66a (64b) Vein $C$ with prehumeral dark spot (PHD) well developed, 3 to 4 times length of humeral pale (HP); anterior mesepimeron with distinct pale scale-patch; upper mesepimeron without pale scales; palpomere $4\left(\mathrm{MPlp}_{4}\right)$ with 4 moderately large scalepatches (Figs. 6a, 7b, 12a) ............................An. darlingi

66b Vein (C) with prehumeral dark spot (PHD) less well-developed, similar in size to humeral pale spot (HP); anterior mesepimeron without a pale scalepatch; upper mesepimeron with a line of pale scales; palpomere $4\left(\mathrm{MPlp}_{4}\right)$ without pale scale-spots ..........67 67a (66b) Wing with prehumeral dark (PHD) and humeral dark (HD) spots small or absent; hindtarsomere $1\left(\mathrm{Ta}-\mathrm{III}_{1}\right)$ with a distinct band of apical pale scales; abdominal tergal scales white............... An. lanei

67b Wing with prehumeral dark (PHD) and humeral dark (HD) spots more developed, larger; hindtarsomere $1\left(\mathrm{Ta}-\mathrm{III}_{1}\right)$ without apical pale scales or with a few pale scales not forming a distinct band; abdominal tergal scales differently colored, never white.................68 68a (67b) Abdominal terga II-IV (II-IV-Te) with reddish scales medially, yellowish scales laterally; vein $\mathrm{C}$ with prehumeral dark spot (PHD) $\leq 0.5$ length of humeral pale spot (HP); hindtarsomere $2\left(\mathrm{Ta}-\mathrm{III}_{2}\right)$ with a band of dark scales on basal 0.15; interocular space wide, $\geq 0.8$ or more diameter of the pedicel......

68b.................................................................. An. sawyeri colored scales medially and some brown mid-apical area; vein $C$ with prehumeral dark spot (PHD) about 0.4-0.8 length of humeral pale spot (HP); hindtarsomere 2 (Ta-III 2 ) usually with a band of dark scales on more than basal 0.15; interocular space moderately wide, $\leq 0.8$ or less diameter of pedicel.. An. argyritarsis

69a (63b) Posterolateral scale-tufts well developed on abdominal tergum II (II-Te): costa (C) with a small sector pale spot $(\mathrm{SP})$; hindtarsomere 2 ( $\mathrm{Ta}-\mathrm{III}_{2}$ ) with dark basal band 0.3-0.4 length of tarsomeres (Fig. 9a) An. braziliensis 
69b Posterolateral scale-tufts absent from abdominal tergum II (II-Te); costa (C) without a sector pale spot (SP); hindtarsomere 2 ( Ta- $\mathrm{III}_{2}$ ) basal dark band variable, $\geq 0.9$ length of tarsomere . . .70

70a (69b) Hindtarsomere $2\left(\mathrm{Ta}-\mathrm{III}_{2}\right)$ with basal dark band $\leq 0.5$ length of tarsomere, sometimes $\geq$ 0.63 length of tarsomere

...An. marajoara, An. janconnae \& An. oryzalimnetes

$70 \mathrm{~b}$ Hindtarsomere $2\left(\mathrm{Ta}-\mathrm{III}_{2}\right)$ with basal band $0.5-$ 0.9 length of tarsomere .

71a (70b) Hindtarsomere 1 (Ta-III ${ }_{1}$ ) with conspicuous apical band of white scales; abdominal terga with posterolateral scale-tufts on segments IV-VII (IV-VII-Te) . An. deaneorum

71b Hindtarsomere 1 ( $\left.\mathrm{Ta}-\mathrm{III}_{1}\right)$ without or with inconspicuous apical band of white scales; abdominal terga with posterolateral scale-tufts on segments III-VII (III-VII-Te) (Figs. 9b, 14) An. albitarsis

\section{Conclusions}

Our identification key, based on morphological characters of adult females, can be used to separate South American subgenera and species of the genus Anopheles. This key will serve a wide range of users. It will be: (i) reliable to a large degree in that many species can be identified definitively using morphological characters, especially if characters from additional life stages can be included; (ii) cost-effective for many. Morphological identification is still much less expensive and less technology-dependent than molecular methods; (iii) a unique research resource for the identification of specimens to morphospecies, which is needed as a basis for molecular studies. Molecular tools are increasingly effective for enhancing Anopheles taxonomy by uncovering similar species, species complexes and sibling species. Identification to morphospecies allows for focus on a subset of individuals rather than having to broadly sample throughout a wide geographical distribution; (iv) a resource for control. Control actions can be justified based on morphological identifications that narrow down to a vector group. Even with the potential of misidentification it is better to assume one is dealing with an effective vector, and that control action is required, rather than to not act at all. This identification key, however, does not allow separation of individual species in a number of informally named groups: i.e. Konderi, Oswaldoi, Nuneztovari, Benarrochi and Albitarsis Complexes, and the Triannulatus and Strodei Groups. In the key these are given species names and designated as "sensu lato". To include component species in future keys, taxonomic studies are needed to name and describe them and to uncover differential characters.

\section{Acknowledgements}

This work would not have been possible without the examination and permission for photographs of specimens from one of the major collections of mosquitoes in South America, repository of valuable reference specimens of multiple species of Anopheles of the Neotropical Region, including primary and secondary type specimens, at the Coleção Entomológica de Referência da Faculdade de Saúde Pública, Universidade de São Paulo, Brazil (FSP-USP). We also thank the Museum of Entomology at the Universidad del Valle, Colombia, for allowing the use of photographic resources and preparing digital images of various parts of its entomological collection. MAMS extends her thanks to the Saúde Pública, Universidade de São Paulo, for their continued support for research projects and the logistics facility for the preparation and maintenance of thousands of specimens of the mosquito collection; and the Fundação de Amparo à Pesquisa do Estado São Paulo for continuous financial support that allowed the execution of hundreds of field sampling efforts for research in the systematics and ecology of mosquitoes (FAPESP Grants \#2014/26229-7; \#2011/20397-7; \#2005/53973-0; CNPq \# 301877/2016 to MAMS). RGO and NSC give special thanks to the Facultad de Ciencias Naturales y Exactas de la Universidad del Valle, Colombia, for continuous support and the logistics facility. Project Amazon Malaria Initiative (AMI) - Amazon Network for the Surveillance of Antimalarial Drug Resistance (RAVREDA) provided partial financial support with assistance from USAID and coordination with PAHO/ WHO. We are in debt to Yvonne-Marie Linton (Walter Reed Army Institute of Research) and Bruce Harrison (in memoriam) for their thoughtful review of the first version of the identification keys for females, males, and larvae, Caio Cesar Moreira, Faculdade de Saúde Pública, Universidade de São Paulo, for final editing of all illustrations, Ralph E. Harbach (Natural History Museum, London, UK) for his thoughtful revision and valuable contribution for the manuscript, and Aneta Kostadinova for her suggestions, corrections, and editing that greatly improved the article. The activities undertaken at WRBU were performed in part under a Memorandum of Understanding between the Walter Reed Army Institute of Research (WRAIR) and the Smithsonian Institution, with institutional support provided by both organizations. The views expressed in this article are those of the authors and do not necessarily reflect the official policy or position of the U.S. Army, the Department of Defense, or the U.S. Government.

\section{Authors' contributions}

MAMS and RCW conceived the study. MAMS, RGO and RCW constructed the identification keys. RGO and NC prepared the illustrations. MAMS, RCW and RGO wrote the manuscript. All authors revised successive drafts of the key. All authors read and approved the final manuscript.

\section{Funding}

This study was funded by the Fundação de Amparo à Pesquisa do Estado de São Paulo (FAPESP) grant no. 2014/26229-7, CNPq grant no. 301877/2016-5 to MAMS; the Armed Forces Health Surveillance Board - Global Emerging Infectious Disease Surveillance (AFHSB-GEIS) [P0116_19_WR_05 and P0140_20_WR_05].

\section{Availability of data and materials}

Specimens used in the current study are deposited and available in the Coleção Entomológica de Referência, Faculdade de Saúde Pública, Universidade de São Paulo (FSP-USP), São Paulo State, Brazil, the US National Mosquito Collection, Smithsonian Institution, Washington, DC, USA (USNMC), and the Facultad de Ciencias Naturales y Exactas de la Universidad del Valle, Colombia.

Ethics approval and consent to participate

Not applicable.

Consent for publication

Not applicable.

Competing interests

The authors declare that they have no competing interests.

\section{Author details}

${ }^{1}$ Departamento de Epidemiologia, Faculdade de Saúde Pública, Universidade de São Paulo, Avenida Doutor Arnaldo 715, São Paulo, São Paulo CEP01246-904, Brazil. ${ }^{2}$ Departamento de Biología, Universidad del Valle, A.A 25360 Cali, Colombia. ${ }^{3}$ Department of Entomology, Smithsonian Institution, 
National Museum of Natural History (NMNH), Washington, DC 20560, USA. ${ }^{4}$ Walter Reed Biosystematics Unit, Smithsonian Institution Museum Support Center, 4210 Silver Hill Rd., Suitland, MD 20746, USA. ${ }^{5}$ Walter Reed Army Institute of Research, 503 Robert Grant Avenue, Silver Spring, MD 20910, USA.

\section{Received: 4 August 2019 Accepted: 10 August 2020}

Published online: 18 November 2020

\section{References}

1. Sallum MAM, Gonzalez Obando R, Carrejo N, Wilkerson RC. Identification keys to the Anopheles mosquitoes of South America (Diptera: Culicidae). I. Introduction. Parasit Vectors. 2020. https://doi.org/10.1186/s13071-02004298-6

2. Sallum MAM, Gonzalez Obando R, Carrejo N, Wilkerson RC. Identification keys to the Anopheles mosquitoes of South America (Diptera: Culicidae) II. Fourth instar larvae. Parasit Vectors. 2020. https://doi.org/10.1186/s1307 1-020-04299-5

3. Sallum MAM, Gonzalez Obando R, Carrejo N, Wilkerson RC. Identification keys to the Anopheles mosquitoes of South America (Diptera: Culicidae). III. Male genitalia. Parasit Vectors. 2020. https://doi.org/10.1186/s1307 1-020-04300-1

4. Bourke BP, Foster PG, Bergo ES, Calado DC, Sallum MA. Phylogenetic relationships among species of Anopheles (Nyssorhynchus) (Diptera, Culicidae) based on nuclear and mitochondrial gene sequences. Acta Trop. 2010;114:88-96.

5. Bourke BP, Nagaki SS, Bergo ES, Cardoso Jda C, Sallum MA. Molecular phylogeny of the Myzorhynchella Section of Anopheles (Nyssorhynchus) (Diptera: Culicidae): genetic support for recently described and resurrected species. Mem Inst Oswaldo Cruz. 2011;106:705-15.

6. Bourke BP, Oliveira TP, Suesdek L, Bergo ES, Sallum MA. A multi-locus approach to barcoding in the Anopheles strodei subgroup (Diptera: Culicidae). Parasit Vectors. 2013;6:111.

7. Calado DC, Foster PG, Bergo ES, Santos CL, Galardo AK, Sallum MA. Resurrection of Anopheles goeldii from synonymy with Anopheles nuneztovari (Diptera, Culicidae) and a new record for Anopheles dunhami in the Brazilian Amazon. Mem Inst Oswaldo Cruz. 2008;103:791-9.

8. Foster PG, Bergo ES, Bourke BP, Oliveira TM, Nagaki SS, Sant'Ana DC, Sallum MA. Phylogenetic analysis and DNA-based species confirmation in Anopheles (Nyssorhynchus). PLoS ONE. 2013;8:e54063.
9. Foster PG, de Oliveira TMP, Bergo ES, Conn JE, Sant'Ana DC, Nagaki SS, et al. Phylogeny of Anophelinae using mitochondrial protein coding genes. R Soc Open Sci. 2017;4:170758.

10. Ruiz-Lopez F, Wilkerson RC, Conn JE, MCKeon SN, Levin DM, Quiñones ML, et al. DNA barcoding reveals both known and novel taxa in the Albitarsis Group (Anopheles: Nyssorhynchus) of Neotropical malaria vectors. Parasit Vectors. 2012;5:44.

11. Ruiz-Lopez F, Wilkerson RC, Ponsonby DJ, Herrera M, Sallum MA, Velez ID, et al. Systematics of the oswaldoi complex (Anopheles, Nyssorhynchus) in South America. Parasit Vectors. 2013;6:324.

12. Sallum MA, Foster PG, Dos Santos CL, Flores DC, Motoki MT, Bergo ES. Resurrection of two species from synonymy of Anopheles (Nyssorhynchus) strode Root, and characterization of a distinct morphological form from the Strodei Complex (Diptera: Culicidae). J Med Entomol. 2010;47:504-26.

13. Wilkerson RC, Foster PG, Li C, Sallum MA. Molecular phylogeny of neotropical Anopheles (Nyssorhynchus) Albitarsis species complex (Diptera: Culicidae). Ann Entomol Soc Am. 2005;98:918-25.

14. Forattini OP. Culicidologia Medica. Identificacão, Biologia, Epidemiologia, vol. II. São Paulo: Editora da Universidade de Sao Paulo; 2002.

15. Wilkerson RC, Strickman D. Illustrated key to the female anopheline mosquitoes of Central America and Mexico. J Am Mosq Control Assoc. 1990;6:7-34.

16. Harrison BA, Ruiz-López F, Calderon Falero G, Savage HM, Pecor JE, Wilkerson RC. Anopheles (Kerteszia) lepidotus (Diptera: Culicidae), not the malaria vector we thought it was: revised male and female morphology; larva, pupa, and male genitalia characters; and molecular verification. Zootaxa. 2012;3218:1-17.

17. Harbach RE, Knight KL. Taxonomists' glossary of mosquito anatomy. Marlton: Plexus Publishing, Inc.; 1980.

18. Harbach RE, Knight KL. Corrections and additions to taxonomists' glossary of mosquito anatomy. Mosq Syst. 1981;1982(13):201-17.

19. Wilkerson RC, Peyton EL. Standardized nomenclature for the costal wing spots of the genus Anopheles and other spotted-winged mosquitoes (Diptera: Culicidae). J Med Entomol. 1990;27:207-24.

\section{Publisher's Note}

Springer Nature remains neutral with regard to jurisdictional claims in published maps and institutional affiliations.
Ready to submit your research? Choose BMC and benefit from:

- fast, convenient online submission

- thorough peer review by experienced researchers in your field

- rapid publication on acceptance

- support for research data, including large and complex data types

- gold Open Access which fosters wider collaboration and increased citations

- maximum visibility for your research: over $100 \mathrm{M}$ website views per year

At BMC, research is always in progress.

Learn more biomedcentral.com/submissions 